\title{
Effect of Cold Storage of Bulbs and Bulb Weight on Growth, Flowering, Essential Oil Components and Bulb Active Ingredients of Narcissus tazetta Plant
}

\author{
Fatma M. Seleem ${ }^{1}$ and S. M. M. Salem ${ }^{* 2}$ \\ ${ }^{1}$ Ornamental Plants Research Department, Horticulture Research Institute, Agric. Research Center, Giza, Egypt \\ ${ }^{2}$ Medicinal and Aromatic Plants Research Dept., Horticulture Research Institute, Agric. Research Center, Giza, Egypt
}

Received: $10 / 3 / 2020$

\begin{abstract}
Field experiments were carried out at the Experimental Farm of El-Kassasin Horticultural Research Station, Ismailia Governorate, Egypt, during two successive seasons (2017-2018 and 2018-2019). To evaluate the effect of cold storage periods $\left(1,2,3,4,5\right.$-weeks at $5^{\circ} \mathrm{C}$ beside room temperature as control) and bulb weight (100, 150 and $\left.200 \pm 5 \mathrm{~g}\right)$ of Narcissus tazetta L. cv. Cheerfullness bulbs on growth, flowering, bulbs production, leaf minerals content and some bulb active ingredients. The results showed positive effects of cold storage and bulb weight as well as the interaction between them on growth, flowering and bulbs production. The highest values of vegetative growth, flower quality and early flowering, bulb yield and mineral content of dry leaves were obtained by the interaction between the longest periods of cold storage (5-weeks) with the highest bulb weight $(200 \mathrm{~g})$. Whereas higher values of active ingredients in dry bulbs, especially antioxidant activity were recorded by the interaction between the cold storage period of two weeks with weights 150 and $100 \mathrm{~g} / \mathrm{bulb}$. These results were recorded in both seasons. All treatments gave differences in essential oil components of flowers.
\end{abstract}

Keywords: Narcissus tazetta, cold storage, bulb weight, growth, flowering, active ingredients, phenols, flavonoids, antioxidants activity, essential oil components

\section{INTRODUCTION}

Ornamental plants are considered one of the very promising crops in Egypt. Narcissus flower is one of the main exportable flowers and the foreign trade, demand Egyptian flowers with high quality and must match the international standers of the exportable flower. Narcissus tazetta L. with the common name of "Narjes" is generally easy to grow, it grows in the winter or spring and is dormant in summer, Narcissus tazetta L. cv. Cheerfulness' is a fragrant, late bloomer with creamy white flowers and yellow flecks.

Narcissus genus, which has as many as eighty species, is the most representative of Amaryllidaceae family (Takos and Rook, 2013). Narcissus is used as an emetic, wound healer, heart and memory intensifier, for the cure of epilepsy and leprosy diseases as well for poliomyelitis and Alzheimer treatments in folk and modern medicine (Orhan and Şener, 2003), also it has important medicinal values currently used in the extraction of alkaloids and flavonoids (Abdel-Rahman, 2017). Bulbs contain flavonoids like rutin, quercetin and kaempferol, phenolic acids (Lubbe et al., 2013), flavonoids particular importance, they have been found to possess antioxidant and free radical scavenging activity (Iwashina, 2000). Also, Bulbs contain a glycoprotein called lectin (Ooi et al., 2000). Narcissus tazetta lectin shows strong inhibitory effects against the respiratory syncytial virus, influenza $A\left(\mathrm{H}_{1} \mathrm{~N}_{1}\right.$, $\mathrm{H}_{3} \mathrm{~N}_{2}, \mathrm{H}_{5} \mathrm{~N}_{1}$ ) and $\mathrm{B}$ viruses (Ooi et al., 2010). Bulb alkaloids have been identified including the antitumor agent narciclasine and galanthamine, Narcissus is one of the oldest known plants in the perfume industry (Remy, 2002). Moreover, Narcissus is critically important for the world trade of cut flowers and bulbs.

Many factors including genotype, location, ecological factors and growth techniques affect the

\footnotetext{
*Corresponding author e-mail: yoyosalah678@gmail.com
}

flowers, bulb quality and bulb yield of Narcissus (Nazki et al., 2005, Özel and Erden, 2018). In addition, the bulb yield is changed dependent on the bulb weight and bulb densities (Khan et al., 2013). Small bulbs do not give flowers or result in products with low market potential (Rees, 1986). Hanks (2002) and Özel and Erden (2018) reported that Narcissus yields are mainly controlled by the grade of bulbs. For this reason, it is important to determine the bulb weight for optimum yield and appropriateness for cut flower and landscape areas.

The storage temperature is a paramount factor that affects the physiological behavior and morphological traits of Narcissus, low temperature period is very important to increasing Narcissus flower production and quality. Increasing cold storage periods of bulbs led to improving growth, flowering quantity and quality, as reported by Toama et al. (2008) and Noy et al. (2010) on Narcissus tazetta, Gomaa (2000) on tuberose, Soliman (2002) on Iris tingitana, El-Bably (2003) on Antholyza aethiopica, El-Bably and Mahmoud (2005) on Tritonia crocata and Thompson et al. (2011) on Lachenalia.

Plant height, inflorescence length, and the number of florets, which are all very important quality features, increased with increasing bulb weight at planting. Bulb yield was increased as the main bulb weight increased. In most cases, flower yield was dependent on bulb weight and earlier inflorescence. In general, inflorescence was improved with increased bulb weight as indicated Özel and Erden (2018) on Narcissus tazetta, Addai and Scott (2011) on hyacinth and the lily, Thompson et al. (2011) and Kapczyńska (2014) on Lachenalia regarding the effect of bulb weight on growth and flowering.

This work was performed to investigate the effect of cold storage periods of bulbs and bulb weight on

Volume 9 (1): 1-12 
growth, flowering, and essential oil components of flowers, bulbs production and some bulb active ingredients of Narcissus tazetta L. cv. Cheerfulness Plant.

\section{MATERIALS AND METHODS}

Two field experiments were carried out at the Experimental Farm of El-Kassasin Horticultural Research Station, Ismailia Governorate, Egypt, during two successive seasons 2017-2018 and 2018-2019. Narcissus tazetta bulbs were obtained from Harraz
Company, Cairo, Egypt. The bulbs were divided into three weights of $200 \pm 5,150 \pm 5$ and $100 \pm 5 \mathrm{~g}$, then they were stored at $5^{\circ} \mathrm{C}$ for $1,2,3,4$ and 5 -weeks in the refrigerator before planting in addition to control treatment (storage at room temperature of $28 \pm 3^{\circ} \mathrm{C}$ ), bulbs were sown in $28^{\text {th }}$ October in both seasons with coated $15 \mathrm{~cm}$ soil. The soil of the experimental field was sandy in texture and its physical and chemical properties are shown in Table (1). Samples of the soil were obtained from $25 \mathrm{~cm}$ soil surface were conducted according to Page et al. (1982) and Klute (1986).

Table (1): Physical and chemical properties of the experimental soil

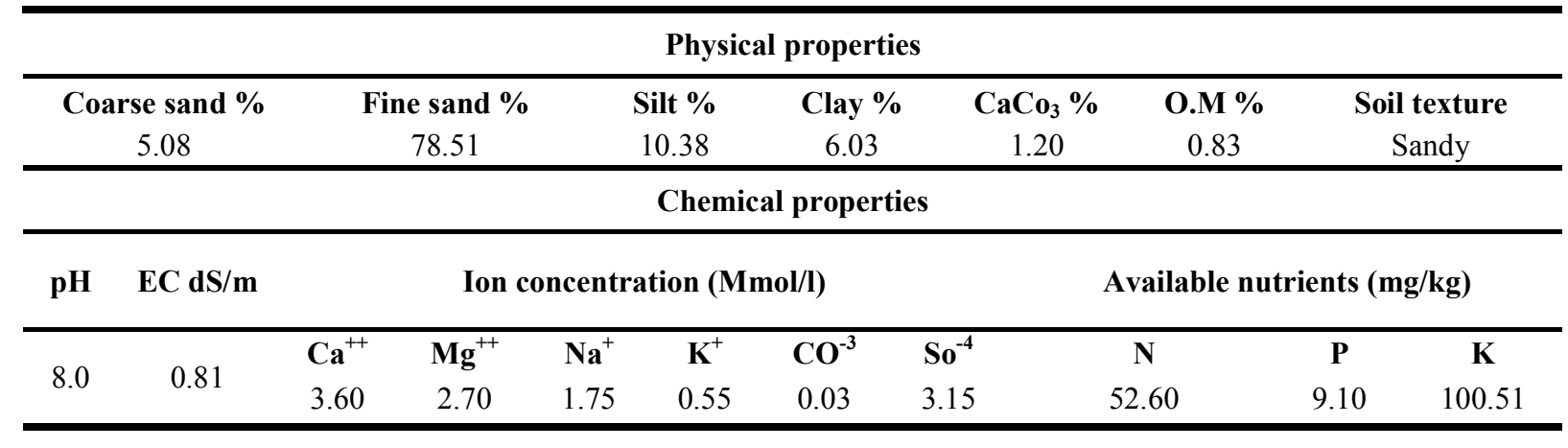

The experiment included 18 treatments were the combination between three bulb weights $(200,150$ and $100 \mathrm{~g})$ treatments and six cold storage treatments (control, 1, 2, 3, 4 and 5-weeks before sowing). The treatments were arranged in a split plot design with three replicates, cold storage treatments were distributed randomly in the main plots, while sub-plots were devoted to the bulb weights.

The experimental unit area was $16.8 \mathrm{~m}^{2}(4.2 \times 4$ $\mathrm{m})$ and each unit contained six rows with $4 \mathrm{~m}$ length for each and $70 \mathrm{~cm}$ width of them. The distance between bulbs was $25 \mathrm{~cm}$ within a row; the four middle rows were used for inflorescences and bulbs yield determination, whereas the two outer rows were used for the determination of plant growth characters. The normal agricultural practices under the drip irrigation system were followed.

\section{Data recorded:}

Growth: Sprout date (days): date on which 70\% appearance of plants occurred at each plot was recorded as sprout date. At flowering stage, leaf length $(\mathrm{cm})$, number of leaves/plant and fresh and dry weights of leaves/plant $(\mathrm{g})$ were recorded.

Flowering: Flowering date (Number of days from planting to the first flower showing colour), flowering period (the period from starting of flowering to the end was determined for randomly selected 20 plants at each plot and their average was recorded)including spike and rachis length $(\mathrm{cm})$ florets number/spike, spike fresh weight $(\mathrm{g})$, diameter of floret $(\mathrm{mm})$, vase-life (days). Vase-life (days) was determined by choosing three similar stalks from each replicate at the stage of opening of the first floret and put in a vase containing distilled water.
Bulbs yield components: At the end of the experiment, on the third week of April for both seasons, the bulbs and bulbils were carefully collected of the soil, air-dried and the following data were recorded: diameter of the main bulb $(\mathrm{mm})$, fresh weight of main bulb (g) and the number of bulbils/plant.

Chemical contents of dry leaves: $\mathrm{N}, \mathrm{P}$ and $\mathrm{K}(\mathrm{mg} / \mathrm{g}$ dry weight) of the fourth inner leaf at the flowering stage were determined according to AOAC (2005).

Some active ingredients and antioxidant activity in the dry bulb: Both total phenols $(\mathrm{mg} / 100 \mathrm{~g})$, total flavonoids (mg/100g) and antioxidant activity (as DPPH radical-scavenging activity, \%) of dry bulbs were determined as described by Youssef and Mokhtar (2014).

Extraction and Gas chromatography analysis of the essential oil: In the second season, the essential oil was extracted from the fresh flowers by ethyl ether solvent. The Gas chromatography (GC) analysis of the essential oil samples was carried out in the Laboratory of Medicinal and Aromatic Plants Research Department, Horticulture Research Institute, ARC using Ds Chrom 6200 Gas Chromatograph apparatus, fitted with a capillary column BPX-5, 5 phenyl (equiv.) polysillphenylene-siloxane $30 \times 0.25 \mathrm{~mm}$ ID $\times 0.25 \mu$ film. The temperature program varied in the range 70 $200^{\circ} \mathrm{C}$, at a rate of $10^{\circ} \mathrm{C} / \mathrm{min}$. Flow rates of gases were nitrogen at $1 \mathrm{ml} / \mathrm{min}$, hydrogen at $30 \mathrm{ml} / \mathrm{min}$ and 330 $\mathrm{ml} / \mathrm{min}$ for air. Detector and injector temperatures were $300^{\circ} \mathrm{C}$ and $250^{\circ} \mathrm{C}$ respectively. The identification of the compounds was done by matching their retention times with those of authentic samples injected under the same conditions. 


\section{Statistical analyses:}

All obtained data were statistically analyzed according to the analysis of variance (ANOVA) for the split plot design as published by Gomez and Gomez (1984) by using "MSTAT-C" computer software package. Least Significant Difference (LSD) was used to test the differences between treatments means at 0.05 level of probability.

\section{RESULTS AND DISCUSSION}

\section{Growth:}

Results in Table (2) testify the effect of cold storage of bulbs at $5^{\circ} \mathrm{C}$ for $1,2,3,4$ and 5-weeks in the refrigerator before planting as compared to control treatment (room temperature) on the growth of Narcissus (leaf length, number of leaves/plant, fresh and dry weight of leaves/plant and sprouting date). It is evident that all growth parameters were improved with all cold storage treatments as compared to control treatment, and were significantly increased with increasing cold storage periods.5-weeks cold storage period recorded the best growth results; also, increasing cold storage gave a short sprout date. The promoted effect of cold storage periods on growth may be due to the stimulatory effect of cold storage on converting the complex stored metabolites in the bulbs to more soluble forms available for plant growth especially by prolonging the storage period (El-Bably and Mahmoud, 2005). Also, may be due to the increase in gibberellin content and activity in the bulbs during cold storage especially by prolonging the period of storage (Nofal et al., 2005). The obtained findings are in agreement with those mentioned by Toama et al. (2008) and Noy et al. (2010) on Narcissus tazetta, Gomaa (2000) on tuberose, Soliman (2002) on some ornamental bulbs, El-Bably (2003) on Antholyza aethiopica and El-Bably and Mahmoud (2005) on Tritonia crocata.

Table (2): Effect of cold storage period and bulb weight on the growth of Narcissus tazetta during seasons 2017/2018 and 2018/2019

\begin{tabular}{|c|c|c|c|c|c|c|c|c|c|c|c|}
\hline \multirow{2}{*}{\multicolumn{2}{|c|}{$\begin{array}{c}\text { Characters } \\
\text { Season }\end{array}$}} & \multicolumn{2}{|c|}{$\begin{array}{l}\text { Leaf length } \\
(\mathrm{cm})\end{array}$} & \multicolumn{2}{|c|}{$\begin{array}{l}\text { Number of } \\
\text { leaves/plant }\end{array}$} & \multicolumn{2}{|c|}{$\begin{array}{l}\text { Fresh weight of } \\
\text { leaves/plant (g) }\end{array}$} & \multicolumn{2}{|c|}{$\begin{array}{c}\text { Dry weight of } \\
\text { leaves/plant (g) }\end{array}$} & \multicolumn{2}{|c|}{$\begin{array}{c}\text { Sprouting date } \\
\text { (days) }\end{array}$} \\
\hline & & $\begin{array}{c}1^{\text {st }} \\
\text { season }\end{array}$ & $\begin{array}{c}2^{\text {nd }} \\
\text { season }\end{array}$ & $\begin{array}{c}1^{\text {st }} \\
\text { season }\end{array}$ & $\begin{array}{c}2^{\text {nd }} \\
\text { season }\end{array}$ & $\begin{array}{c}1^{\text {st }} \\
\text { season }\end{array}$ & $\begin{array}{c}2^{\text {nd }} \\
\text { season }\end{array}$ & $\begin{array}{c}1^{\text {st }} \\
\text { season }\end{array}$ & $\begin{array}{c}2^{\text {nd }} \\
\text { season }\end{array}$ & $\begin{array}{c}1^{\text {st }} \\
\text { season }\end{array}$ & $\begin{array}{c}2^{\text {nd }} \\
\text { season }\end{array}$ \\
\hline \multicolumn{2}{|c|}{ Treatments } & \multicolumn{10}{|c|}{ Cold storage periods (week) } \\
\hline \multirow{2}{*}{\multicolumn{2}{|c|}{$\begin{array}{l}\text { Control } \\
1 \text { Week }\end{array}$}} & 26.79 & 27.76 & 15.41 & 16.48 & 132.98 & 134.31 & 6.11 & 6.89 & 28.64 & 27.93 \\
\hline & & 28.05 & 28.73 & 16.73 & 17.79 & 137.31 & 136.85 & 7.22 & 7.67 & 26.96 & 26.38 \\
\hline \multicolumn{2}{|c|}{2 Weeks } & 29.73 & 29.74 & 17.74 & 18.91 & 139.63 & 139.98 & 7.98 & 8.33 & 25.49 & 25.16 \\
\hline \multicolumn{2}{|c|}{3 Weeks } & 30.65 & 31.77 & 18.85 & 20.21 & 141.58 & 142.96 & 8.55 & 9.23 & 23.83 & 23.07 \\
\hline \multicolumn{2}{|c|}{4 Weeks } & 31.46 & 32.81 & 19.74 & 21.97 & 143.76 & 146.75 & 9.49 & 10.03 & 22.62 & 21.82 \\
\hline \multicolumn{2}{|c|}{5 Weeks } & 32.10 & 33.68 & 21.12 & 23.46 & 146.57 & 150.34 & 10.05 & 11.13 & 20.23 & 19.22 \\
\hline \multicolumn{2}{|c|}{$\mathbf{L S D}_{\mathbf{0 . 0 5}}$} & 2.07 & 1.89 & 2.88 & 1.77 & 3.42 & 2.77 & 1.13 & 1.07 & 3.18 & 2.64 \\
\hline & & \multicolumn{10}{|c|}{ Bulb weight (g) } \\
\hline \multicolumn{2}{|c|}{$200 \mathrm{~g}$} & 30.14 & 31.04 & 18.71 & 20.27 & 141.41 & 143.08 & 8.43 & 9.22 & 23.95 & 23.30 \\
\hline \multicolumn{2}{|c|}{$150 \mathrm{~g}$} & 29.82 & 30.77 & 18.32 & 19.79 & 140.35 & 141.82 & 8.21 & 8.88 & 24.76 & 23.95 \\
\hline \multicolumn{2}{|c|}{$100 \mathrm{~g}$} & 29.44 & 30.44 & 17.76 & 19.35 & 139.16 & 140.73 & 8.05 & 8.54 & 25.17 & 24.55 \\
\hline \multicolumn{2}{|c|}{$\mathbf{L S D}_{0.05}$} & 0.33 & 0.27 & 0.40 & 0.19 & 1.02 & 1.08 & 0.06 & 0.08 & 1.01 & 0.71 \\
\hline & & \multicolumn{10}{|c|}{ Interaction } \\
\hline \multirow{4}{*}{ Control } & $200 \mathrm{~g}$ & 27.34 & 27.99 & 15.77 & 17.04 & 135.25 & 135.26 & 6.21 & 7.11 & 28.01 & 27.34 \\
\hline & $150 \mathrm{~g}$ & 26.87 & 27.84 & 15.41 & 16.34 & 133.45 & 134.21 & 6.11 & 6.79 & 28.77 & 28.01 \\
\hline & $100 \mathrm{~g}$ & 26.15 & 27.44 & 15.06 & 16.07 & 130.24 & 133.45 & 6.01 & 6.77 & 29.14 & 28.45 \\
\hline & $200 \mathrm{~g}$ & 28.25 & 29.01 & 17.09 & 18.00 & 138.24 & 137.46 & 7.64 & 7.99 & 26.45 & 26.00 \\
\hline \multirow[t]{3}{*}{1 Week } & $150 \mathrm{~g}$ & 28.01 & 28.78 & 16.88 & 17.92 & 137.24 & 136.88 & 7.24 & 7.67 & 27.01 & 26.14 \\
\hline & $100 \mathrm{~g}$ & 27.88 & 28.40 & 16.21 & 17.44 & 136.44 & 136.21 & 6.77 & 7.34 & 27.41 & 27.01 \\
\hline & $200 \mathrm{~g}$ & 29.99 & 30.11 & 18.11 & 19.47 & 140.43 & 141.34 & 8.08 & 8.44 & 25.00 & 24.41 \\
\hline \multirow[t]{3}{*}{2 Weeks } & $150 \mathrm{~g}$ & 29.77 & 29.68 & 17.92 & 19.01 & 139.48 & 140.11 & 7.99 & 8.42 & 25.47 & 25.31 \\
\hline & $100 \mathrm{~g}$ & 29.44 & 29.44 & 17.19 & 18.25 & 138.99 & 138.49 & 7.88 & 8.12 & 26.01 & 25.77 \\
\hline & $200 \mathrm{~g}$ & 31.05 & 32.01 & 19.21 & 20.75 & 142.23 & 144.23 & 8.78 & 9.72 & 23.10 & 22.71 \\
\hline \multirow[t]{3}{*}{3 Weeks } & $150 \mathrm{~g}$ & 30.78 & 31.87 & 18.87 & 20.02 & 141.64 & 142.77 & 8.44 & 9.21 & 24.05 & 23.00 \\
\hline & $100 \mathrm{~g}$ & 30.11 & 31.44 & 18.46 & 19.87 & 140.88 & 141.89 & 8.42 & 8.77 & 24.33 & 23.49 \\
\hline & $200 \mathrm{~g}$ & 31.77 & 33.21 & 19.99 & 22.45 & 144.33 & 147.99 & 9.67 & 10.22 & 22.00 & 21.34 \\
\hline \multirow[t]{3}{*}{4 Weeks } & $150 \mathrm{~g}$ & 31.45 & 32.77 & 19.76 & 22.01 & 143.75 & 147.15 & 9.45 & 10.11 & 22.76 & 22.00 \\
\hline & $100 \mathrm{~g}$ & 31.15 & 32.45 & 19.47 & 21.45 & 143.21 & 145.11 & 9.34 & 9.770 & 23.10 & 22.13 \\
\hline & $200 \mathrm{~g}$ & 32.41 & 33.89 & 22.11 & 23.89 & 147.99 & 152.01 & 10.22 & 11.85 & 19.16 & 18.01 \\
\hline \multirow[t]{2}{*}{5 Weeks } & $150 \mathrm{~g}$ & 32.01 & 33.69 & 21.07 & 23.45 & 146.51 & 149.77 & 10.04 & 11.07 & 20.48 & 19.21 \\
\hline & $100 \mathrm{~g}$ & 31.89 & 33.45 & 20.18 & 23.04 & 145.21 & 149.24 & 9.88 & 10.48 & 21.04 & 20.45 \\
\hline LSI & & 3.33 & 3.18 & 1.99 & 2.01 & 3.07 & 2.72 & 1.14 & 1.08 & 2.44 & 3.01 \\
\hline
\end{tabular}


As for the effect of bulb weights (100, 150 and $200 \mathrm{~g}$ ) on the vegetative growth of Narcissus, data of both seasons are shown in Table (2). The leaf length, the number of leaves/plant and fresh and dry weight of leaves/plant were significantly increased with increasing bulb weight. In the same trend, sprouting time was shorted with bulb weight increasing. These results are logic since the heavy weight contains more stored metabolites, necessary for better growth. These results agree with those obtained by Nazki et al. (2005), Khan et al. (2013), Özel and Erden (2018) on Narcissus tazetta, El-Bably (2003) on Antholyza aethiopica, Thompson et al. (2011) and Kapczyńska (2014) on Lachenalia.

Concerning the effect of interaction between cold storage period and bulb weight on growth, the data in Table (2), revealed that all interaction treatments had a significant effect on the vegetative growth of Narcissus plants. The heavy bulbs $(200 \mathrm{~g})$ that cold stored for 5 weeks gave the highest growth values, on the other hand, the small bulbs (100 g) stored in room temperature recorded the lowest growth values.

\section{Flowering:}

Data in Table (3) indicated that, the different cold storage treatments tended to cause a steady and significant precocity in flowering by prolonging cold storage period compared with bulbs stored at room temperature during both seasons, and chilling had very promising effects on the acceleration and earliness of flowering. Increasing cold storage period decreased flowering date and increased both spike and rachis lengths and fresh weight of spike, while the bulbs stored at room temperature increased flowering date and decreased both spike and rachis lengths and fresh weight of spike. The increase in flowering traits may be due to the promoted effect on growth traits that reflected on flowering. In addition, inflorescence initiation occurs during the cold storage period and the temperature must be the most important environmental factor affecting the rate of development at this stage (El-Bably and Mahmoud, 2005). Similar findings obtained by Toama et al. (2008) and Noy et al. (2010) on Narcissus tazetta, El-Bably and Mahmoud (2005) on Tritonia crocata and Thompson et al. (2011) on Lachenalia.

The results in Table (3) demonstrated that bulb weight treatments improved flowering characters (flowering date, spike and rachis lengths and spike fresh weight). There was a significant and gradual increase in spike and rachis lengths and spike fresh weight by increasing bulb weight, while, the flowering date was shorted by increasing bulb weight. The increase in flower characters may be due to the aforementioned reasons in the case of vegetative growth as vigorous growth may reflect on flowers. The present results were conflicted with those of Khan et al. (2013) on Narcissus tazetta and Thompson et al. (2011) on Lachenalia.

As regards the interaction between the two studied factors, it is obvious from the results in Table (3) that, the highest values of spike and rachis lengths and spike fresh weight resulted from planting heavy bulbs $(200 \mathrm{~g})$ which were stored for 5 -weeks at $5^{\circ} \mathrm{C}$, while planting small bulbs (100 g) which stored in room temperature gave the least values. On the other hand, the flowering date was shorten when using big bulbs $(200 \mathrm{~g})$ which were stored for 5 -weeks at $5^{\circ} \mathrm{C}$ as compared to small bulbs that stored in room temperature

\section{Flowering quality:}

As shown in Table (4) it is interesting to note that, there were significant effects of all cold storage treatments on flowering quality (floret diameter, flowering period and vase-life), except the number of florets/spike in both seasons compared with untreated bulbs (room temperature). Where the significant increase in flowering quality appeared under the longest cold storage period treatment (5-week) compared with the other treatments. Slight and insignificant increment in the number of florets/spike was observed due to prolonging of cold storage period. This character may be due to genotypic of variety (Baker et al., 2000). The increase in vase-life by prolonging cold storage period may be due to the enhancement of vegetative growth traits under such conditions, several investigators found that cold storage improved flowering quality e.g. Noy et al. (2010) on Narcissus tazetta and Nofal et al. (2005) on Antholyza aethiopica.

The results in Table (4) revealed that increasing bulb weight from 100 to $200 \mathrm{~g}$ caused a significant increase of floret diameter, flowering period and vaselife, and insignificant differences in the number of florets/spike. In addition, small bulbs give small flowers with low market potential. The increase in flower quality may be due to improve vegetative growth as the vigorous growth may reflect on flowers quality. These results are in agreement with those obtained by Özel and Erden (2018) on Narcissus tazetta and Kapczyńska (2014) on Lachenalia.

Regarding to the interaction treatments between cold storage and bulb weight, it is evident from data in Table (4) that prolonging cold storage period (5-weeks) coupled with heavy bulbs (200 g) gave the significantly longest floret diameter, flowering period and vase-life, which outranked any other treatments, but the number of florets/spike show insignificant effect by any interaction3treatments. In the same trend, sowing small bulbs stored in room temperature showed the lowest values of flowering quality traits.

\section{Bulb yield components:}

It is apparent in Table (5) that increasing cold storage period in both seasons caused a significant and progressive increase in the diameter of the main bulb, fresh weight of main bulb and number of bulbits/plant over control treatment. Where the highest values were obtained from the stored bulbs for 5 -weeks at $5^{\circ} \mathrm{C}$, the lowest values were obtained from the stored bulbs in room temperature.

This result was probably due to that prolonging cold storage period led to the accumulation of more soluble metabolites necessary for rapid and vigorous plant growth, which reflected on storing the new bulbits for more reserve materials after the harvesting of spikes. Result of Noy et al. (2010) on Narcissus tazetta and Nofal et al. (2005) on Antholyza aethiopica supported our result. 
Table (3): Effect of cold storage period and bulb weight on flowering of Narcissus tazetta during seasons 2017/2018 and $2018 / 2019$

\begin{tabular}{|c|c|c|c|c|c|c|c|c|c|}
\hline \multirow{2}{*}{\multicolumn{2}{|c|}{$\begin{array}{c}\text { Characters } \\
\text { Season }\end{array}$}} & \multicolumn{2}{|c|}{$\begin{array}{l}\text { Flowering date } \\
\text { (days) }\end{array}$} & \multicolumn{2}{|c|}{$\begin{array}{l}\text { Spike length } \\
\text { (cm) }\end{array}$} & \multicolumn{2}{|c|}{$\begin{array}{c}\text { Spike fresh weight } \\
\text { (g) }\end{array}$} & \multicolumn{2}{|c|}{$\begin{array}{l}\text { Rachis length } \\
(\mathbf{m m})\end{array}$} \\
\hline & & $\begin{array}{c}1^{\text {st }} \\
\text { season }\end{array}$ & $\begin{array}{c}2^{\text {nd }} \\
\text { season }\end{array}$ & $\begin{array}{c}1^{\text {st }} \\
\text { season }\end{array}$ & $\begin{array}{c}2^{\text {nd }} \\
\text { season }\end{array}$ & $\begin{array}{c}1^{\text {st }} \\
\text { season }\end{array}$ & $\begin{array}{c}2^{\text {nd }} \\
\text { season }\end{array}$ & $\begin{array}{c}1^{\text {st }} \\
\text { season }\end{array}$ & $\begin{array}{c}2^{\text {nd }} \\
\text { season }\end{array}$ \\
\hline \multicolumn{2}{|c|}{ Treatments } & \multicolumn{8}{|c|}{ Cold storage periods (week) } \\
\hline \multicolumn{2}{|c|}{ Control } & 64.10 & 62.58 & 29.72 & 30.80 & 158.14 & 162.07 & 33.48 & 34.90 \\
\hline \multicolumn{2}{|c|}{1 Week } & 61.23 & 60.48 & 32.16 & 32.94 & 163.33 & 166.90 & 34.59 & 36.85 \\
\hline \multicolumn{2}{|c|}{2 Weeks } & 58.07 & 56.73 & 34.44 & 34.99 & 169.58 & 172.18 & 37.24 & 38.48 \\
\hline \multicolumn{2}{|c|}{3 Weeks } & 54.98 & 54.48 & 36.24 & 36.48 & 174.84 & 177.12 & 39.48 & 40.68 \\
\hline \multicolumn{2}{|c|}{4 Weeks } & 51.77 & 52.15 & 37.44 & 38.35 & 178.72 & 180.66 & 42.78 & 42.76 \\
\hline \multicolumn{2}{|c|}{5 Weeks } & 49.22 & 49.40 & 38.70 & 39.78 & 184.70 & 186.69 & 46.28 & 45.51 \\
\hline \multicolumn{2}{|c|}{$\mathbf{L S D}_{0.05}$} & 4.31 & 3.27 & 1.11 & 2.31 & 5.67 & 4.36 & 1.13 & 1.44 \\
\hline & & \multicolumn{8}{|c|}{ Bulb weight (g) } \\
\hline \multicolumn{2}{|c|}{$200 \mathrm{~g}$} & 55.57 & 55.157 & 35.43 & 36.21 & 173.20 & 176.03 & 39.67 & 40.50 \\
\hline \multicolumn{2}{|c|}{$150 \mathrm{~g}$} & 56.56 & 55.877 & 34.80 & 35.55 & 171.66 & 174.27 & 39.06 & 39.91 \\
\hline \multicolumn{2}{|c|}{$100 \mathrm{~g}$} & 57.55 & 56.878 & 34.12 & 34.92 & 169.80 & 172.51 & 38.20 & 39.19 \\
\hline \multicolumn{2}{|c|}{$\mathbf{L S D}_{0.05}$} & 1.12 & 0.82 & 0.33 & 0.41 & 1.43 & 1.29 & 0.03 & 0.11 \\
\hline & & \multicolumn{8}{|c|}{ Interaction } \\
\hline \multirow{3}{*}{ Control } & $200 \mathrm{~g}$ & 62.77 & 62.09 & 30.24 & 31.48 & 159.45 & 163.88 & 33.77 & 35.21 \\
\hline & $150 \mathrm{~g}$ & 64.31 & 62.44 & 29.77 & 30.77 & 158.21 & 162.34 & 33.47 & 34.99 \\
\hline & $100 \mathrm{~g}$ & 65.21 & 63.21 & 29.14 & 30.15 & 156.77 & 160.00 & 33.21 & 34.51 \\
\hline \multirow{3}{*}{1 Week } & $200 \mathrm{~g}$ & 60.00 & 60.00 & 32.88 & 33.69 & 165.21 & 169.00 & 35.00 & 37.48 \\
\hline & $150 \mathrm{~g}$ & 61.44 & 60.24 & 32.15 & 33.01 & 163.47 & 166.45 & 34.77 & 36.87 \\
\hline & $100 \mathrm{~g}$ & 62.24 & 61.21 & 31.45 & 32.12 & 161.32 & 165.24 & 34.00 & 36.21 \\
\hline \multirow{3}{*}{2 Weeks } & $200 \mathrm{~g}$ & 57.21 & 56.00 & 35.44 & 35.77 & 172.00 & 174.22 & 38.00 & 39.00 \\
\hline & $150 \mathrm{~g}$ & 58.00 & 56.74 & 34.40 & 35.00 & 170.00 & 172.31 & 37.25 & 38.45 \\
\hline & $100 \mathrm{~g}$ & 58.99 & 57.44 & 33.48 & 34.19 & 166.74 & 170.00 & 36.48 & 37.99 \\
\hline \multirow{3}{*}{3 Weeks } & $200 \mathrm{~g}$ & 54.30 & 53.41 & 37.01 & 37.21 & 176.34 & 178.88 & 40.00 & 41.21 \\
\hline & $150 \mathrm{~g}$ & 55.00 & 54.62 & 36.24 & 36.23 & 174.78 & 177.00 & 39.45 & 40.84 \\
\hline & $100 \mathrm{~g}$ & 55.64 & 55.41 & 35.46 & 36.01 & 173.41 & 175.47 & 38.99 & 40.00 \\
\hline \multirow{3}{*}{4 Weeks } & $200 \mathrm{~g}$ & 51.06 & 51.44 & 37.88 & 38.77 & 180.00 & 181.77 & 44.21 & 43.88 \\
\hline & $150 \mathrm{~g}$ & 51.48 & 52.01 & 37.45 & 38.41 & 179.15 & 181.20 & 43.21 & 42.64 \\
\hline & $100 \mathrm{~g}$ & 52.77 & 53.00 & 37.00 & 37.88 & 177.00 & 179.00 & 40.91 & 41.77 \\
\hline \multirow{3}{*}{5 Weeks } & $200 \mathrm{~g}$ & 48.10 & 48.00 & 39.11 & 40.32 & 186.21 & 188.41 & 47.01 & 46.21 \\
\hline & $150 \mathrm{~g}$ & 49.11 & 49.21 & 38.77 & 39.88 & 184.33 & 186.33 & 46.21 & 45.64 \\
\hline & $100 \mathrm{~g}$ & 50.44 & 51.00 & 38.21 & 39.15 & 183.54 & 185.32 & 45.61 & 44.67 \\
\hline \multicolumn{2}{|c|}{$\mathbf{L S D}_{0.05}$} & 3.33 & 2.97 & 2.07 & 1.88 & 5.16 & 4.61 & 2.33 & 3.18 \\
\hline
\end{tabular}


Table (4): Effect of cold storage period and bulb weight on flower quality of Narcissus tazetta during seasons 2017/2018 and 2018/2019

\begin{tabular}{|c|c|c|c|c|c|c|c|c|c|}
\hline \multicolumn{2}{|c|}{ Characters } & \multicolumn{2}{|c|}{$\begin{array}{l}\text { Number of } \\
\text { florets/spike }\end{array}$} & \multicolumn{2}{|c|}{$\begin{array}{l}\text { Floret diameter } \\
\qquad(\mathrm{mm})\end{array}$} & \multicolumn{2}{|c|}{$\begin{array}{c}\text { Flowering period } \\
\text { (days) }\end{array}$} & \multicolumn{2}{|c|}{$\begin{array}{l}\text { Vase life } \\
\text { (days) }\end{array}$} \\
\hline \multicolumn{2}{|c|}{ Season } & $\begin{array}{c}1^{\text {st }} \\
\text { season } \\
\end{array}$ & $\begin{array}{c}2^{\text {nd }} \\
\text { season } \\
\end{array}$ & $\begin{array}{c}1^{\text {st }} \\
\text { season } \\
\end{array}$ & $\begin{array}{c}2^{\text {nd }} \\
\text { season } \\
\end{array}$ & $\begin{array}{c}1^{\text {st }} \\
\text { season } \\
\end{array}$ & $\begin{array}{c}2^{\text {nd }} \\
\text { season } \\
\end{array}$ & $\begin{array}{c}1^{\text {st }} \\
\text { season } \\
\end{array}$ & $\begin{array}{c}2^{\text {nd }} \\
\text { season } \\
\end{array}$ \\
\hline \multicolumn{2}{|c|}{ Treatments } & \multicolumn{8}{|c|}{ Cold storage periods (week) } \\
\hline \multicolumn{2}{|c|}{ Control } & 6.12 & 6.22 & 34.29 & 33.91 & 18.44 & 18.81 & 4.33 & 4.33 \\
\hline \multicolumn{2}{|c|}{1 Week } & 6.34 & 6.31 & 36.50 & 35.80 & 19.52 & 19.52 & 4.85 & 4.71 \\
\hline \multicolumn{2}{|c|}{2 Weeks } & 6.36 & 6.40 & 39.56 & 36.79 & 21.17 & 21.55 & 5.29 & 5.49 \\
\hline \multicolumn{2}{|c|}{3 Weeks } & 6.45 & 6.45 & 41.93 & 37.85 & 22.69 & 23.29 & 5.71 & 6.13 \\
\hline \multicolumn{2}{|c|}{4 Weeks } & 6.51 & 6.49 & 43.08 & 40.98 & 23.74 & 24.51 & 6.04 & 6.60 \\
\hline \multicolumn{2}{|c|}{5 Weeks } & 6.50 & 6.56 & 44.42 & 43.59 & 24.59 & 24.96 & 6.32 & 7.01 \\
\hline \multicolumn{2}{|c|}{ LSD $_{0.05}$} & N.S & N.S & 1.79 & 2.04 & 1.10 & 0.87 & 1.13 & 1.08 \\
\hline & & \multicolumn{8}{|c|}{ Bulb weight (g) } \\
\hline \multicolumn{2}{|c|}{$200 \mathrm{~g}$} & 6.41 & 6.42 & 40.50 & 38.50 & 22.07 & 22.44 & 5.59 & 5.89 \\
\hline \multicolumn{2}{|c|}{$150 \mathrm{~g}$} & 6.36 & 6.41 & 40.03 & 38.18 & 21.71 & 22.11 & 5.41 & 5.68 \\
\hline \multicolumn{2}{|c|}{$100 \mathrm{~g}$} & 6.37 & 6.39 & 39.36 & 37.79 & 21.30 & 21.77 & 5.28 & 5.57 \\
\hline \multicolumn{2}{|c|}{$\mathbf{L S D}_{0.05}$} & N.S & N.S & 0.11 & 0.23 & 0.29 & 0.42 & 0.18 & 0.09 \\
\hline & & \multicolumn{8}{|c|}{ Interaction } \\
\hline \multirow{3}{*}{ Control } & $200 \mathrm{~g}$ & 6.11 & 6.23 & 34.99 & 34.25 & 18.77 & 19.00 & 4.67 & 4.43 \\
\hline & $150 \mathrm{~g}$ & 6.15 & 6.21 & 34.67 & 34.01 & 18.33 & 18.77 & 4.22 & 4.31 \\
\hline & $100 \mathrm{~g}$ & 6.11 & 6.22 & 33.21 & 33.47 & 18.21 & 18.66 & 4.11 & 4.26 \\
\hline \multirow{3}{*}{1 Week } & $200 \mathrm{~g}$ & 6.44 & 6.33 & 37.24 & 36.00 & 19.88 & 19.87 & 4.90 & 4.88 \\
\hline & $150 \mathrm{~g}$ & 6.34 & 6.29 & 36.48 & 35.74 & 19.67 & 19.44 & 4.88 & 4.69 \\
\hline & $100 \mathrm{~g}$ & 6.24 & 6.31 & 35.78 & 35.66 & 19.01 & 19.24 & 4.76 & 4.55 \\
\hline \multirow{3}{*}{2 Weeks } & $200 \mathrm{~g}$ & 6.44 & 6.41 & 40.47 & 37.00 & 21.88 & 22.00 & 5.45 & 5.69 \\
\hline & $150 \mathrm{~g}$ & 6.22 & 6.44 & 39.45 & 36.89 & 21.01 & 21.64 & 5.32 & 5.46 \\
\hline & $100 \mathrm{~g}$ & 6.42 & 6.34 & 38.77 & 36.48 & 20.63 & 21.01 & 5.11 & 5.31 \\
\hline \multirow{3}{*}{3 Weeks } & $200 \mathrm{~g}$ & 6.46 & 6.46 & 42.31 & 38.12 & 23.00 & 23.99 & 5.88 & 6.27 \\
\hline & $150 \mathrm{~g}$ & 6.45 & 6.46 & 41.88 & 37.88 & 22.77 & 23.14 & 5.71 & 6.11 \\
\hline & $100 \mathrm{~g}$ & 6.44 & 6.44 & 41.61 & 37.55 & 22.31 & 22.74 & 5.55 & 6.00 \\
\hline \multirow{3}{*}{4 Weeks } & $200 \mathrm{~g}$ & 6.50 & 6.50 & 43.37 & 41.61 & 24.00 & 24.77 & 6.21 & 6.88 \\
\hline & $150 \mathrm{~g}$ & 6.52 & 6.49 & 43.21 & 41.00 & 23.77 & 24.66 & 6.00 & 6.52 \\
\hline & $100 \mathrm{~g}$ & 6.51 & 6.47 & 42.67 & 40.34 & 23.44 & 24.11 & 5.91 & 6.41 \\
\hline \multirow{3}{*}{5 Weeks } & $200 \mathrm{~g}$ & 6.50 & 6.570 & 44.62 & 44.00 & 24.89 & 25.00 & 6.41 & 7.12 \\
\hline & $150 \mathrm{~g}$ & 6.50 & 6.570 & 44.51 & 43.55 & 24.68 & 25.00 & 6.33 & 7.00 \\
\hline & $100 \mathrm{~g}$ & 6.49 & 6.550 & 44.13 & 43.21 & 24.21 & 24.88 & 6.22 & 6.90 \\
\hline LSD & & N.S & N.S & 3.77 & 4.35 & 2.08 & 1.84 & 0.99 & 1.02 \\
\hline
\end{tabular}

Results in Table (5) reveal the effect of bulb weight $(100,150$ and $200 \mathrm{~g})$ on the diameter and fresh weight of the main bulb as well as the number of bulbits/plant, it is evident that increasing the bulb yield was seen concomitantly with increasing bulb weight. This may be due to the heavy bulbs producing a higher number of bulbils. The increase in the fresh weight of the main bulb may be due to the aforementioned reasons in case of vegetative growth as the vigorous growth may reflect on the production of heavier bulbs. These results were in agreement with those obtained by Nazki et al. (2005), Khan et al. (2013), Özel and Erden
(2018) on Narcissus tazetta and El-Bably (2003) on Antholyza aethiopica, as well as Thompson et al. (2011) and Kapczyńska (2014) on Lachenalia.

Concerning the interaction between the two studied factors, data in Table (5) proved that the longest cold storage (5-weeks) with the heavy bulbs $(200 \mathrm{~g})$ recorded the highest values of diameter and fresh weight of the main bulb as well as number of bulbits/plant compared with the other interaction treatments. Meanwhile, small bulbs stored in room temperature recorded the lowest values of these traits. 
Table (5): Effect of cold storage period and bulb weight on bulbs yield components of Narcissus tazetta during seasons 2017/2018 and 2018/2019

\begin{tabular}{|c|c|c|c|c|c|c|c|}
\hline \multicolumn{2}{|c|}{ Characters } & \multicolumn{2}{|c|}{$\begin{array}{c}\text { Diameter of main bulb } \\
(\mathrm{cm})\end{array}$} & \multicolumn{2}{|c|}{$\begin{array}{c}\text { Fresh weight of main bulb } \\
(\mathrm{g})\end{array}$} & \multicolumn{2}{|c|}{$\begin{array}{c}\text { Number of bulbits/ } \\
\text { plant }\end{array}$} \\
\hline \multicolumn{2}{|c|}{ Season } & $1^{\text {st }}$ season & $2^{\text {nd }}$ season & $1^{\text {st }}$ season & $2^{\text {nd }}$ season & $1^{\text {st }}$ season & $2^{\text {nd }}$ season \\
\hline \multicolumn{2}{|c|}{ Treatments } & \multicolumn{6}{|c|}{ Cold storage periods (week) } \\
\hline $\begin{array}{l}\text { Co } \\
1 \text { V } \\
2 \mathrm{~V} \\
3 \mathrm{~V} \\
4 \mathrm{~V} \\
5 \mathrm{~V}\end{array}$ & & $\begin{array}{c}7.33 \\
8.09 \\
8.69 \\
9.47 \\
10.24 \\
10.74 \\
\end{array}$ & $\begin{array}{c}7.54 \\
7.99 \\
8.57 \\
9.19 \\
9.84 \\
10.63 \\
\end{array}$ & $\begin{array}{c}95.07 \\
121.47 \\
165.16 \\
194.08 \\
209.58 \\
229.17 \\
\end{array}$ & $\begin{array}{c}97.01 \\
118.99 \\
136.22 \\
165.59 \\
206.03 \\
224.23 \\
\end{array}$ & $\begin{array}{l}4.52 \\
5.20 \\
6.26 \\
7.35 \\
8.06 \\
8.43 \\
\end{array}$ & $\begin{array}{l}4.46 \\
5.15 \\
5.89 \\
6.60 \\
7.20 \\
7.90 \\
\end{array}$ \\
\hline \multicolumn{2}{|c|}{$\mathbf{L S D}_{0.05}$} & 1.08 & 0.92 & 4.69 & 5.31 & 1.62 & 1.77 \\
\hline & & \multicolumn{6}{|c|}{ Bulb weight (g) } \\
\hline \multicolumn{2}{|c|}{$\begin{array}{l}200 \mathrm{~g} \\
150 \mathrm{~g} \\
100 \mathrm{~g} \\
\end{array}$} & $\begin{array}{r}9.28 \\
9.10 \\
8.91 \\
\end{array}$ & $\begin{array}{l}9.18 \\
8.96 \\
8.75 \\
\end{array}$ & $\begin{array}{l}174.81 \\
169.59 \\
162.87 \\
\end{array}$ & $\begin{array}{l}163.55 \\
158.04 \\
152.45 \\
\end{array}$ & $\begin{array}{l}6.92 \\
6.61 \\
6.38 \\
\end{array}$ & $\begin{array}{l}6.41 \\
6.19 \\
6.00 \\
\end{array}$ \\
\hline \multirow{2}{*}{\multicolumn{2}{|c|}{$\mathbf{L S D}_{0.05}$}} & 0.11 & 0.30 & 2.49 & 3.62 & 0.22 & 0.33 \\
\hline & & \multicolumn{6}{|c|}{ Interaction } \\
\hline Control & $\begin{array}{l}200 \mathrm{~g} \\
150 \mathrm{~g} \\
100 \mathrm{~g}\end{array}$ & $\begin{array}{l}7.44 \\
7.34 \\
7.21\end{array}$ & $\begin{array}{l}7.66 \\
7.54 \\
7.42\end{array}$ & $\begin{array}{l}99.67 \\
94.77 \\
90.77\end{array}$ & $\begin{array}{l}99.21 \\
97.46 \\
94.36\end{array}$ & $\begin{array}{l}4.87 \\
4.47 \\
4.21\end{array}$ & $\begin{array}{l}4.65 \\
4.41 \\
4.33\end{array}$ \\
\hline 1 Week & $\begin{array}{l}200 \mathrm{~g} \\
150 \mathrm{~g} \\
100 \mathrm{~g}\end{array}$ & $\begin{array}{l}8.25 \\
8.14 \\
7.89\end{array}$ & $\begin{array}{l}8.22 \\
7.99 \\
7.77\end{array}$ & $\begin{array}{l}130.42 \\
123.77 \\
110.21\end{array}$ & $\begin{array}{l}123.00 \\
118.67 \\
115.31\end{array}$ & $\begin{array}{l}5.39 \\
5.21 \\
5.01\end{array}$ & $\begin{array}{l}5.44 \\
5.21 \\
4.79\end{array}$ \\
\hline 2 Weeks & $\begin{array}{l}200 \mathrm{~g} \\
150 \mathrm{~g} \\
100 \mathrm{~g}\end{array}$ & $\begin{array}{l}9.00 \\
8.75 \\
8.33\end{array}$ & $\begin{array}{l}8.73 \\
8.56 \\
8.41\end{array}$ & $\begin{array}{l}172.31 \\
166.47 \\
156.69\end{array}$ & $\begin{array}{l}142.20 \\
137.14 \\
129.33\end{array}$ & $\begin{array}{l}6.79 \\
6.21 \\
5.77\end{array}$ & $\begin{array}{l}6.00 \\
5.87 \\
5.80\end{array}$ \\
\hline 3 Weeks & $\begin{array}{l}200 \mathrm{~g} \\
150 \mathrm{~g} \\
100 \mathrm{~g}\end{array}$ & $\begin{array}{l}9.77 \\
9.44 \\
9.21\end{array}$ & $\begin{array}{l}9.44 \\
9.14 \\
9.00\end{array}$ & $\begin{array}{l}200.18 \\
192.33 \\
189.74\end{array}$ & $\begin{array}{l}175.11 \\
163.44 \\
158.23\end{array}$ & $\begin{array}{l}7.69 \\
7.34 \\
7.01\end{array}$ & $\begin{array}{l}6.90 \\
6.60 \\
6.29\end{array}$ \\
\hline 4 Weeks & $\begin{array}{l}200 \mathrm{~g} \\
150 \mathrm{~g} \\
100 \mathrm{~g}\end{array}$ & $\begin{array}{l}10.33 \\
10.21 \\
10.17\end{array}$ & $\begin{array}{c}10.00 \\
9.87 \\
9.66\end{array}$ & $\begin{array}{l}211.67 \\
209.77 \\
207.31\end{array}$ & $\begin{array}{l}213.44 \\
207.33 \\
197.33\end{array}$ & $\begin{array}{l}8.21 \\
7.99 \\
7.99\end{array}$ & $\begin{array}{l}7.49 \\
7.12 \\
7.00\end{array}$ \\
\hline 5 Weeks & $\begin{array}{l}200 \mathrm{~g} \\
150 \mathrm{~g} \\
100 \mathrm{~g}\end{array}$ & $\begin{array}{l}10.88 \\
10.72 \\
10.62\end{array}$ & $\begin{array}{l}11.00 \\
10.66 \\
10.23\end{array}$ & $\begin{array}{l}234.60 \\
230.45 \\
222.47\end{array}$ & $\begin{array}{l}228.34 \\
224.21 \\
220.14\end{array}$ & $\begin{array}{l}8.55 \\
8.42 \\
8.31\end{array}$ & $\begin{array}{l}8.00 \\
7.90 \\
7.80\end{array}$ \\
\hline & & 1.49 & 2.01 & 5.66 & 4.12 & 4.66 & 3.08 \\
\hline
\end{tabular}

Control: Room temperature

\section{Chemical contents of dry leaves:}

Data in Table (6) show the effect of the cold storage period of bulbs on mineral contents of dry leaves. Cold storage treatments showed gradual increases in NPK contents of leaves compared with control treatment (room temperature) in both seasons. The highest NPK contents were recorded with the longest period of cold storage (5-week) with significant differences compared to control. The promoting effect of cold storage treatments on NPK content in the leaves may be due to the enhancement of vegetative growth and acceleration of sprouting, which allowed more absorption of such elements from the soil as reflected on increasing its content in the leaves. This result explains the action of cold storage on improving the growth through the stimulation of enzymatic phosphorus system. Similar results were obtained by
El-Bably (2003) on Antholyza aethiopica, El-Bably and Mahmoud (2005) on Tritonia crocata.

As obvious from Table (6), the bulb weight has significant effects on NPK contents in the dry leaves of Narcissus, heavy bulbs (200 g) recorded significant increases in NPK contents as compared to small bulbs $(100 \mathrm{~g})$. These results supported by the results recorded by Özel and Erden (2018) on Narcissus tazetta and Kapczyńska (2014) on Lachenalia.

As regards the interaction between the study factors, it is obvious from the results in Table (6) that, the highest values of NPK contents resulted from using heavy bulbs $(200 \mathrm{~g})$, which were stored for 5-weeks at $5^{\circ} \mathrm{C}$. Meanwhile, sowing the small bulbs $(100 \mathrm{~g})$ which were stored in room temperature recorded the lowest NPK values with insignificant differences in most cases. 
Table (6): Effect of cold storage period and bulb weight on NPK content in Narcissus tazetta leaves during seasons $2017 / 2018$ and $2018 / 2019$

\begin{tabular}{|c|c|c|c|c|c|c|c|}
\hline \multirow{2}{*}{\multicolumn{2}{|c|}{$\frac{\text { Characters }}{\text { Season }}$}} & \multicolumn{2}{|c|}{ Nitrogen $\%$} & \multicolumn{2}{|c|}{ Phosphorus \% } & \multicolumn{2}{|c|}{ Potassium \% } \\
\hline & & $1^{\text {st }}$ season & $2^{\text {nd }}$ season & $1^{\text {st }}$ season & $2^{\text {nd }}$ season & $1^{\text {st }}$ season & $2^{\text {nd }}$ season \\
\hline \multicolumn{2}{|c|}{ Treatments } & \multicolumn{6}{|c|}{ Cold storage periods (week) } \\
\hline \multicolumn{2}{|c|}{ Control } & 0.79 & 0.79 & 0.44 & 0.45 & 0.70 & 0.71 \\
\hline \multicolumn{2}{|c|}{1 Week } & 0.85 & 0.85 & 0.47 & 0.47 & 0.74 & 0.74 \\
\hline \multicolumn{2}{|c|}{2 Weeks } & 0.90 & 0.90 & 0.50 & 0.51 & 0.77 & 0.77 \\
\hline \multicolumn{2}{|c|}{3 Weeks } & 0.94 & 0.95 & 0.55 & 0.54 & 0.82 & 0.81 \\
\hline \multicolumn{2}{|c|}{4 Weeks } & 0.98 & 0.99 & 0.59 & 0.57 & 0.86 & 0.83 \\
\hline \multicolumn{2}{|c|}{5 Weeks } & 1.01 & 1.02 & 0.59 & 0.60 & 0.90 & 0.85 \\
\hline \multicolumn{2}{|c|}{ LSD $_{0.05}$} & 0.16 & 0.12 & 0.08 & 0.06 & 0.12 & 0.08 \\
\hline & & \multicolumn{6}{|c|}{ Bulb weight (g) } \\
\hline \multirow{3}{*}{\multicolumn{2}{|c|}{$\begin{array}{l}200 \mathrm{~g} \\
150 \mathrm{~g} \\
100 \mathrm{~g}\end{array}$}} & 0.93 & 0.94 & 0.54 & 0.54 & 0.82 & 0.81 \\
\hline & & 0.91 & 0.92 & 0.52 & 0.52 & 0.80 & 0.79 \\
\hline & & 0.89 & 0.90 & 0.51 & 0.51 & 0.78 & 0.77 \\
\hline \multicolumn{2}{|c|}{$\mathrm{LSD}_{0.05}$} & 0.03 & 0.02 & 0.01 & 0.02 & 0.03 & 0.02 \\
\hline & & \multicolumn{6}{|c|}{ Interaction } \\
\hline \multirow{4}{*}{ Control } & $200 \mathrm{~g}$ & 0.80 & 0.82 & 0.46 & 0.46 & 0.72 & 0.73 \\
\hline & $150 \mathrm{~g}$ & 0.79 & 0.79 & 0.44 & 0.45 & 0.70 & 0.70 \\
\hline & $100 \mathrm{~g}$ & 0.78 & 0.77 & 0.43 & 0.44 & 0.68 & 0.70 \\
\hline & $200 \mathrm{~g}$ & 0.88 & 0.87 & 0.49 & 0.49 & 0.75 & 0.76 \\
\hline \multirow[t]{3}{*}{1 Week } & $150 \mathrm{~g}$ & 0.83 & 0.85 & 0.47 & 0.47 & 0.74 & 0.75 \\
\hline & $100 \mathrm{~g}$ & 0.83 & 0.83 & 0.46 & 0.45 & 0.72 & 0.72 \\
\hline & $200 \mathrm{~g}$ & 0.91 & 0.92 & 0.52 & 0.53 & 0.79 & 0.79 \\
\hline \multirow[t]{3}{*}{2 Weeks } & $150 \mathrm{~g}$ & 0.90 & 0.89 & 0.49 & 0.50 & 0.77 & 0.77 \\
\hline & $100 \mathrm{~g}$ & 0.88 & 0.89 & 0.49 & 0.49 & 0.75 & 0.75 \\
\hline & $200 \mathrm{~g}$ & 0.96 & 0.97 & 0.57 & 0.56 & 0.84 & 0.83 \\
\hline \multirow[t]{3}{*}{3 Weeks } & $150 \mathrm{~g}$ & 0.94 & 0.95 & 0.55 & 0.53 & 0.82 & 0.81 \\
\hline & $100 \mathrm{~g}$ & 0.92 & 0.93 & 0.53 & 0.52 & 0.80 & 0.79 \\
\hline & $200 \mathrm{~g}$ & 0.99 & 1.01 & 0.60 & 0.59 & 0.88 & 0.86 \\
\hline \multirow[t]{3}{*}{4 Weeks } & $150 \mathrm{~g}$ & 0.98 & 0.99 & 0.59 & 0.58 & 0.86 & 0.84 \\
\hline & $100 \mathrm{~g}$ & 0.96 & 0.98 & 0.57 & 0.55 & 0.83 & 0.80 \\
\hline & $200 \mathrm{~g}$ & 1.04 & 1.06 & 0.62 & 0.63 & 0.94 & 0.88 \\
\hline \multirow[t]{2}{*}{5 Weeks } & $150 \mathrm{~g}$ & 0.99 & 1.02 & 0.58 & 0.60 & 0.88 & 0.85 \\
\hline & $100 \mathrm{~g}$ & 0.99 & 0.99 & 0.58 & 0.58 & 0.88 & 0.83 \\
\hline \multicolumn{2}{|c|}{$\mathrm{LSD}_{0.05}$} & 0.23 & 0.17 & 0.09 & 0.07 & 0.04 & 0.05 \\
\hline
\end{tabular}

Control: Room temperature

Some active ingredients and antioxidant activity in the dry bulb:

Data regarding the total phenols, total flavonoids and antioxidant activity in dry bulbs of Narcissus tazetta during the two seasons were recorded in Table (7). Total phenols arranged from 325.51 to $553.44 \mathrm{mg} / 100 \mathrm{~g}$, total flavonoids arranged from 774.30 to $1412.69 \mathrm{mg} / 100 \mathrm{~g}$ and antioxidant activity arranged from 26.50 to $41.88 \%$ in the two seasons. Total phenols, total flavonoids and antioxidant activity were significantly increased by increasing the cold storage period up to 2-week. Cold storage for 2-week gave significant increases in these components compared to control and the other cold storage treatments for the first and second seasons. The lowest content of these components was obtained by the longest cold storage period in most cases.

All active ingredients under study were significantly affected by the bulb weight as clear in Table (7). Total flavonoids and antioxidant activity in dry bulbs were significantly increased by decreasing bulb weight. While, the highest contents of total phenols were recorded with the medium weight ( $150 \mathrm{~g} / \mathrm{bulb})$, the lowest weight $(100 \mathrm{~g} / \mathrm{bulb})$ gave the highest contents of both total flavonoids and antioxidant activity with significant differences in the two seasons. The lowest contents of all these components were obtained with the highest weight (200 g/bulb) for both seasons.

While the interaction treatment between 2-week cold storage and $150 \mathrm{~g} / \mathrm{bulb}$ weight recorded the highest values of total phenols for the two seasons and total flavonoids in the first one, the interaction treatment between 2 -week cold storage and $100 \mathrm{~g} /$ bulb recorded the highest content of total flavonoids in the second season, and the highest antioxidant activity in both seasons, with significant differences compared to the other treatments. The lowest phenols content was recorded with the interaction treatment between 4-week cold storage and $100 \mathrm{~g} /$ bulb in the two seasons. Interaction between 5week cold storage and both of $150 \mathrm{~g}$ and $100 \mathrm{~g} / \mathrm{bulb}$ recorded the lowest contents of total flavonoids and antioxidant activity, respectively, for both seasons with significant differences compared to all other treatments. 
Table (7): Effect of cold storage period and bulb weight on some active ingredients in Narcissus tazetta bulbs during seasons 2017/2018 and 2018/2019

\begin{tabular}{|c|c|c|c|c|c|c|c|}
\hline \multirow{2}{*}{\multicolumn{2}{|c|}{$\begin{array}{c}\text { Characters } \\
\text { Season }\end{array}$}} & \multicolumn{2}{|c|}{$\begin{array}{l}\text { Total Phenols } \\
\text { mg/100g d.w. }\end{array}$} & \multicolumn{2}{|c|}{$\begin{array}{l}\text { Total Flavonoids } \\
\text { mg/100 g d.w. }\end{array}$} & \multicolumn{2}{|c|}{$\begin{array}{c}\text { Antioxidant activity } \\
\%\end{array}$} \\
\hline & & $1^{\text {st }}$ season & $2^{\text {nd }}$ season & $1^{\text {st }}$ season & $2^{\text {nd }}$ season & $1^{\text {st }}$ season & $2^{\text {nd }}$ season \\
\hline \multicolumn{2}{|c|}{ Treatments } & \multicolumn{6}{|c|}{ Cold storage periods (week) } \\
\hline \multicolumn{2}{|c|}{ Control } & 465.54 & 463.94 & 1041.11 & 1048.02 & 33.65 & 33.17 \\
\hline \multicolumn{2}{|c|}{1 Week } & 477.62 & 470.44 & 1152.93 & 1140.76 & 36.27 & 34.52 \\
\hline \multicolumn{2}{|c|}{2 Weeks } & 553.44 & 546.17 & 1412.69 & 1366.62 & 41.37 & 41.88 \\
\hline \multicolumn{2}{|c|}{3 Weeks } & 373.56 & 371.11 & 994.77 & 1019.10 & 26.50 & 27.91 \\
\hline \multicolumn{2}{|c|}{4 Weeks } & 358.44 & 375.19 & 1196.27 & 1140.09 & 27.72 & 28.64 \\
\hline \multicolumn{2}{|c|}{5 Weeks } & 330.47 & 325.51 & 817.48 & 774.30 & 27.45 & 26.98 \\
\hline \multicolumn{2}{|c|}{$\mathbf{L S D}_{0.05}$} & 7.28 & 4.30 & 18.68 & 14.07 & 0.84 & 0.43 \\
\hline & & \multicolumn{6}{|c|}{ Bulb weight (g) } \\
\hline \multicolumn{2}{|c|}{$200 \mathrm{~g}$} & 398.19 & 396.18 & 1036.17 & 1010.05 & 29.63 & 30.19 \\
\hline \multicolumn{2}{|c|}{$150 \mathrm{~g}$} & 454.77 & 465.98 & 1115.18 & 1071.21 & 31.45 & 32.56 \\
\hline \multicolumn{2}{|c|}{$100 \mathrm{~g}$} & 426.57 & 414.02 & 1156.26 & 1163.20 & 35.39 & 33.80 \\
\hline \multicolumn{2}{|c|}{$\operatorname{LSD}_{0.05}$} & 5.04 & 5.53 & 14.04 & 10.01 & 0.30 & 0.29 \\
\hline & & \multicolumn{6}{|c|}{ Interaction } \\
\hline \multirow{3}{*}{ Control } & $200 \mathrm{~g}$ & 399.85 & 398.26 & 953.29 & 984.20 & 26.33 & 25.92 \\
\hline & $150 \mathrm{~g}$ & 495.03 & 505.39 & 911.41 & 930.36 & 34.29 & 34.40 \\
\hline & $100 \mathrm{~g}$ & 501.73 & 488.18 & 1258.62 & 1229.51 & 40.33 & 39.19 \\
\hline \multirow{3}{*}{1 Week } & $200 \mathrm{~g}$ & 356.77 & 338.96 & 1004.25 & 899.95 & 26.68 & 26.40 \\
\hline & $150 \mathrm{~g}$ & 500.77 & 495.75 & 1314.27 & 1324.24 & 39.47 & 38.28 \\
\hline & $100 \mathrm{~g}$ & 575.33 & 576.62 & 1140.26 & 1198.10 & 42.66 & 38.88 \\
\hline \multirow{3}{*}{2 Weeks } & $200 \mathrm{~g}$ & 427.34 & 429.90 & 1001.75 & 996.17 & 33.17 & 34.680 \\
\hline & $150 \mathrm{~g}$ & 680.56 & 687.26 & 1676.74 & 1542.12 & 38.76 & 41.493 \\
\hline & $100 \mathrm{~g}$ & 552.42 & 521.34 & 1559.57 & 1561.56 & 52.18 & 49.463 \\
\hline \multirow{3}{*}{3 Weeks } & $200 \mathrm{~g}$ & 434.07 & 446.09 & 1262.41 & 1274.38 & 28.63 & 31.07 \\
\hline & $150 \mathrm{~g}$ & 332.15 & 339.18 & 847.69 & 845.10 & 24.21 & 26.58 \\
\hline & $100 \mathrm{~g}$ & 354.45 & 328.07 & 874.21 & 937.84 & 26.67 & 26.09 \\
\hline \multirow{3}{*}{4 Weeks } & $200 \mathrm{~g}$ & 407.94 & 430.42 & 1030.57 & 1021.60 & 31.81 & 32.72 \\
\hline & $150 \mathrm{~g}$ & 397.94 & 413.11 & 1226.02 & 1088.41 & 24.44 & 26.40 \\
\hline & $100 \mathrm{~g}$ & 269.44 & 282.03 & 1332.22 & 1310.28 & 26.90 & 26.81 \\
\hline \multirow{3}{*}{5 Weeks } & $200 \mathrm{~g}$ & 363.20 & 333.45 & 964.76 & 883.99 & 31.19 & 30.37 \\
\hline & $150 \mathrm{~g}$ & 322.18 & 355.17 & 714.97 & 697.02 & 27.54 & 28.18 \\
\hline & $100 \mathrm{~g}$ & 306.03 & 287.92 & 772.70 & 741.89 & 23.63 & 22.38 \\
\hline \multicolumn{2}{|c|}{$\operatorname{LSD}_{0.05}$} & 12.35 & 13.55 & 34.40 & 24.37 & 0.74 & 0.70 \\
\hline
\end{tabular}




\section{Essential oil components:}

Data regarding essential oil components in Narcissus flowers illustrated in Table (8).They reveal that the main identified components were $\beta$-Ocimene (45.31-81.46\%), Limonene (1.02-9.56\%), 1,8-Cineole (0.72-5.40\%), Linalool (0.41-8.91\%), Benzyl acetate $(0.78-13.83 \%)$ and $\beta$-Caryophyllene (4.12-22.33\%). Cold storage treatments recorded differences in essential oil components, whereas 4-week cold storage gave the highest content of $\beta$-Ocimene, 1-week recorded the highest content of Limonene. While the highest contents of 1,8-Cineole and Linalool were obtained by cold storage for 2-week, the highest content of $\beta$-caryophyllene was obtained by cold storage for 3-week.Moreover, the bulbs storage at room temperature (control) recorded the highest Benzyl acetate content. Furthermore, the lowest contents of most of these components were obtained with 4 and 5-week cold storage treatments.

As shown in Table (8) essential oil constituents were affected by bulb weight, $200 \mathrm{~g}$ bulbs gave the highest content of 1,8-Cineole and Benzyl acetate, but $150 \mathrm{~g}$ bulbs gave the highest content of both Limonene and Linalool. While the highest contents of $\beta$-Ocimene and $\beta$-caryophyllene were obtained with bulbs have $100 \mathrm{~g}$ weight. The highest weight $(200 \mathrm{~g})$ of bulb gave the lowest values of $\beta$-Ocimene, Linalool and $\beta$ caryophyllene, whereas the lowest weight $(100 \mathrm{~g})$ recorded the lowest values of Limonene and Benzyl acetate.

The interaction between 1-week cold storage and bulb weights 200 and $150 \mathrm{~g}$ recorded the highest content of both Limonene and Linalool, respectively. While bulbs have 200 and $100 \mathrm{~g}$ weight were stored at room temperature (control) gave the highest content of both Benzyl acetate and $\beta$-caryophyllene, respectively, the lowest bulb weight $(100 \mathrm{~g})$ with 2 -week cold storage period recorded the highest content of 1,8 Cineole. The long cold storage periods (4 and 5-week) with 100 and $150 \mathrm{~g}$ bulbs recorded the highest content of $\beta$-Ocimene.

\section{CONCLUSION}

From the obtained results, it could be concluded that the highest values of vegetative growth, flower quality and early flowering, vase-life and bulb yield were obtained by the interaction between the longest periods of cold storage (5-weeks) with the highest bulb weight $(200 \mathrm{~g})$. Whereas the higher values of active ingredients in dry bulbs, especially antioxidants activity were recorded by the interaction between the cold storage period of 2-weeks with weights 150 and $100 \mathrm{~g} / \mathrm{bulb}$, in both seasons. All treatments gave differences in essential oil components of flowers.

\section{REFERENCES}

AOAC (2005). Association of Official Agricultural Chemists Official Methods of Analysis. $18^{\text {th }}$ Ed. Washington, D.C. USA.

Abdel-Rahman, H. M., A. M. F. Al-Ansary, K. N. Rashed and A. A. Rizkalla (2017).
Micropropagation of Narcissus tazetta 'Chinensis' and its relation to secondary metabolites content. Journal of Applied Life Sciences International, 14(1): 1-11.

Addai, I. K. and P. Scott (2011). Influence of bulb size at planting on growth and development of the common hyacinth and the lily. Agriculture and Biology Journal of North America, 2: 298-314.

Baker, A. M., J. D. Thompson and S. C. H. Barrett (2000). Evolution and maintenance of stigma height dimorphism in Narcissus: I. Floral variation and style-morph ratios. Heredity, 84: $502-513$

El-Bably, S. M. Z. (2003). Studies on some factors affecting productivity of some ornamental bulbs. Ph.D. Thesis, Fac. Agric. Kafr ElSheikh, Tanta Univ.

El-Bably, S. M. Z. and A. M. A. Mahmoud (2005). Effects of corms storage, zinc application and their interaction on vegetative growth, flowering, corms productivity and chemical constituents of Tritonia crocata kergawl. Plant. https://www.researchgate.net/ publication/ 324546341

Gomaa, S. A. A. (2000). Physiological studies on Polianthes tuberosa and Ornithogalum thyrsoides bulbs. Ph.D. Thesis, Fac. Agric., Kafr El-Sheikh, University.

Gomez, A. K. and A. A. Gomez (1984). Statistical procedures for agricultural research. $2^{\text {nd }} E d$., John Willy and Sons, New York, USA.

Hanks, G. R. (2002). Commercial Production of Narcissus Bulbs. In: Narcissus and Daffodil, Hanks, G.R. (Ed.). Taylor and Francis Limited, pp.: 53-131.

Iwashina, T. (2000). The structure and distribution of the flavonoids in plants. J. Plant Res., 113: 287-299.

Kapczyńska, A. (2014). Effect of bulb size on growth, flowering and bulb formation in Lachenalia cultivars. Hort. Sci., 41: (2) 89-94.

Khan, I. M., F. U. Khan, M. Salmani, M. H. Khan, M. A. Mir and H. Amir (2013). Effect of bulb density, nitrogen application time and deheading on growth, yield and relative economics of daffodil cv. Tunis (Narcissus sp.). African Journal of Agricultural Research, 8(31): 4189-4193.

Klute, A. (1986). Methods of soil analysis: part 1. physical and mineralogical methods $\left(2^{\text {nd }} E d\right.$. $)$ Amer. Soc. Agron. Monograph No. 9. Madison-Wisconsin. U.S.A.

Lubbe, A., H. Gude, R. Verpoorte and Y. H. Choi (2013). Seasonal accumulation of major alkaloids in organs of pharmaceutical crop Narcissus Carlton. Phytochemistry, 88: 43-53.

Nazki, I. T., F. U. Khan, Z. A. Qadri, T. M. Paul and M. Q. Sheikh (2005). Effect of crop duration, planting density and bulb grade on foliar, floral and bulb growth in Narcissus tazetta Linn. cv. Paper White Grandiflorus. Journal of Ornamental Horticulture (New Series), 8(3): 222-224. 
Table (8): Effect of bulbs weight and cold storage periods of bulbs on essential oil components of Narcissus tazetta L. cv. Cheerfulness during the season $2018-2019$

\begin{tabular}{|c|c|c|c|c|c|c|c|c|c|c|c|c|c|c|}
\hline \multirow{3}{*}{ Component \% } & \multicolumn{14}{|c|}{ Treatments } \\
\hline & \multicolumn{3}{|c|}{ Control } & \multicolumn{3}{|c|}{1 week } & \multicolumn{2}{|c|}{2 weeks } & \multicolumn{2}{|c|}{3 weeks } & \multirow{2}{*}{$\frac{4 \text { weeks }}{100 \mathrm{~g}}$} & \multicolumn{3}{|c|}{5 weeks } \\
\hline & $200 \mathrm{~g}$ & $150 \mathrm{~g}$ & $100 \mathrm{~g}$ & $200 \mathrm{~g}$ & $150 \mathrm{~g}$ & $100 \mathrm{~g}$ & $200 \mathrm{~g}$ & $100 \mathrm{~g}$ & $200 \mathrm{~g}$ & $150 \mathrm{~g}$ & & $200 \mathrm{~g}$ & $150 \mathrm{~g}$ & $100 \mathrm{~g}$ \\
\hline$\beta$-Ocimene & 60.56 & 58.99 & 62.63 & 60.30 & 54.47 & 69.29 & 55.21 & 64.23 & 65.71 & 62.63 & 81.46 & 73.50 & 81.46 & 45.31 \\
\hline Limonene & 9.19 & 8.77 & ---- & 9.56 & 9.06 & ---- & 9.03 & 3.93 & 3.67 & ---- & ---- & ---- & ---- & 1.02 \\
\hline 1,8-Cineole & 3.58 & 3.41 & 0.96 & 1.48 & ---- & 1.57 & ---- & 5.40 & 4.78 & 0.96 & 2.43 & 0.72 & 2.43 & ---- \\
\hline Linalool & 2.66 & 2.54 & 3.25 & 2.77 & 8.91 & 4.50 & 8.69 & 6.49 & 5.23 & 3.25 & ---- & 0.41 & ---- & 1.79 \\
\hline Benzyl acetate & 13.83 & 13.20 & 2.07 & 13.53 & 11.16 & 0.55 & 11.33 & 7.16 & 8.18 & 2.06 & 0.78 & 0.37 & 0.78 & 9.02 \\
\hline$\beta$-Caryophyllene & 7.22 & 6.89 & 22.33 & 6.79 & 5.84 & ---- & 6.23 & 8.64 & 8.62 & 22.33 & 4.86 & 4.12 & 4.86 & 20.76 \\
\hline Identified components & 97.04 & 93.80 & 91.24 & 94.43 & 89.44 & 75.91 & 90.49 & 95.85 & 96.19 & 91.23 & 89.53 & 79.12 & 89.53 & 77.90 \\
\hline \multirow{2}{*}{ Component \% } & \multicolumn{14}{|c|}{ Means of Treatments } \\
\hline & $200 \mathrm{~g}$ & $150 \mathrm{~g}$ & & $100 \mathrm{~g}$ & Control & & 1 weeks & 2 weeks & & 3 weeks & 4 weeks & 5 weeks & & $\begin{array}{l}\text { Mean } \\
\text { comp. }\end{array}$ \\
\hline$\beta$-Ocimene & 63.06 & 64.39 & & 64.58 & 60.73 & & 61.35 & 59.72 & & 64.17 & 81.46 & 66.76 & & 64.01 \\
\hline Limonene & 7.86 & 8.92 & & 2.48 & 8.98 & & 9.31 & 6.48 & & 3.67 & ---- & 1.02 & & 6.09 \\
\hline 1,8-Cineole & 2.64 & 2.27 & & 2.59 & 2.65 & & 1.53 & 5.40 & & 2.87 & 2.43 & 1.58 & & 2.66 \\
\hline Linalool & 3.95 & 4.90 & & 4.01 & 2.82 & & 5.39 & 7.59 & & 4.24 & ---- & 1.10 & & 4.25 \\
\hline Benzyl acetate & 9.45 & 6.80 & & 3.92 & 9.70 & & 8.41 & 9.25 & & 5.12 & 0.78 & 3.39 & & 6.31 \\
\hline$\beta$-Caryophyllene & 6.60 & 9.98 & & 14.15 & 12.15 & & 6.32 & 7.44 & & 15.48 & 4.86 & 9.91 & & 9.56 \\
\hline Identified components & 93.56 & 97.26 & & 91.73 & 97.03 & & 95.31 & 95.88 & & 95.55 & 89.53 & 83.76 & & \\
\hline
\end{tabular}

Control: Room temperature 
Nofal, E. M, M. A. El-Tarawy, M. M. Khalafallah, S. M. Shahin and Samia, Z. El-Bably (2005). Effect of corm storage treatments and corm size on vegetative growth, flowering, corms productivity and some chemical constituents of Antholyza aethiopica, L. The $6^{\text {th }}$ Arabian Conference for Horticulture, Ismailia, Egypt, 28-38.

Noy, P. T., R. Kamenetsky, A. Eshel and M. A. Flaishman (2010). Temporal and spatial expression patterns of the leafy homologue NLF during florogenesis in Narcissus tazetta. Plant Science, 178: 105-113.

Ooi, L. S. M., T. B. Ng, Yunqi Geng and V. E. C. Ooi (2000). Lectins from bulbs of the Chinese daffodil Narcissus tazetta (family Amaryllidaceae). Biochemistry and Cell Biology, 78(4): 463-468.

Ooi, L. S. M., W-S. Ho, K. L. K. Ngai, L. Tian, P. K. S. Chan, S. S. M. Sun and V. E. C. Ooi (2010). Narcissus tazetta lectin shows strong inhibitory effects against respiratory syncytial virus, influenza $A\left(\mathrm{H}_{1} \mathrm{~N}_{1}, \mathrm{H}_{3} \mathrm{~N}_{2}\right.$, $\mathrm{H}_{5} \mathrm{~N}_{1}$ ) and B viruses. J. Biosci., 35: 95-103.

Orhan, I. and B. Şener (2003). Bioactivity-directed fractionation of alkaloids from some Amaryllidaceae plants and their Anticholinesterase activity. Chemistry of Natural Compounds, 39(4): 383-386.

Özel, A. and K. Erden (2018). The effect of bulb sizes on the bulb yield and some plant characteristics of Narcissus tazetta subsp. tazetta L. Harran Tarımve Gida Bilimleri Derg, 22(3): 355-362.

Page, A. L., R. H. Miller and D. R. Keeny (1982). Methods of soil analysis part II. Chemical and microbiological properties $\left(2^{\text {nd }} E d\right.$. $)$.
Amer. Soc. Agron. Monograph No. 9. Madison-Wisconsin. U.S.A.

Rees, A. R. (1986). Narcissus: Flowers per tonne of bulbs. ISHS Acta Horticulturae, 177: IV International Symposium on Flower Bulbs, R. J. Bogers, B. H. H. Bergman (Eds.), Vol. 1, pp.: 261-266.

Remy, C. (2002). Narcissus in Perfumery. In: Narcissus and Daffodil. Taylor and Francis Limited, Hanks, G. R. (Ed.). pp.: 392-398.

Soliman, M. A. (2002). Physiological and anatomical studies on some ornamental bulbs. Ph.D. Thesis, Fac. Agric., Kafr El-Sheikh University.

Takos, A. M. and F. Rook (2013). Towards a molecular understanding of the biosynthesis of Amaryllidaceae alkaloids in support of their expanding medical use. International Journal of Molecular Sciences, 14(6): 11713- 41.

Thompson, D. I., N. P. Mtshali, G. D. Ascough, J. E. Erwin and J. Van Staden (2011). Flowering control in Watsonia: Effects of corm size, temperature, photoperiod and irradiance. Scientia Horticulturae, 129: 493-502.

Toama, N. M., S. M. Mohamed and R. A. Farahat (2008). Response of Narcissus tazetta growth and flowering to cold storage treatments. Acta Horticulturae, No.786: 253-259.

Youssef, K. M. and S. M. Mokhtar (2014). Effect of Drying Methods on the Antioxidant Capacity, Color and Phytochemicals of Portulacaoleracea L. leaves. J. Nutr. Food Sci., 4(6): 1-6. http://dx.doi.org/10.4172/21559600.1000322

$$
\begin{aligned}
& \text { تأثير التخزين البارد للأبصال ووزن البصلة على النمو والتزهير ومكونات الزيت العطري ومكونات }
\end{aligned}
$$

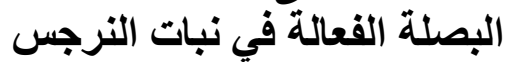

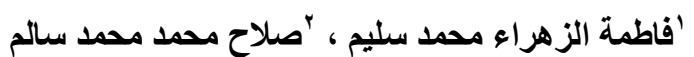

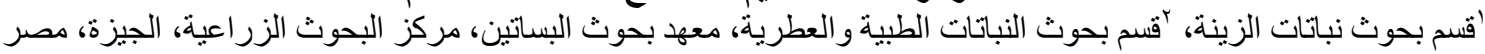

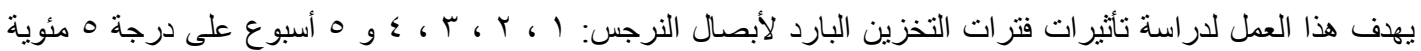

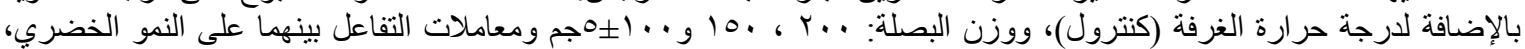

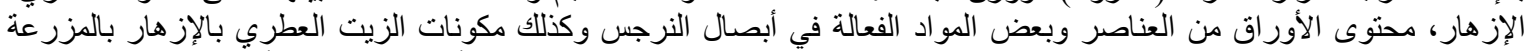

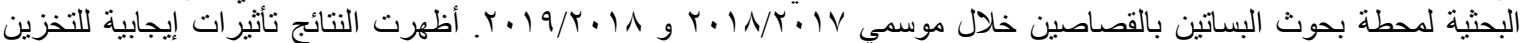

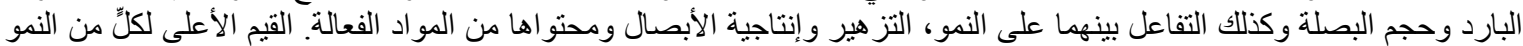

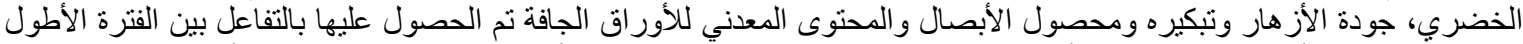

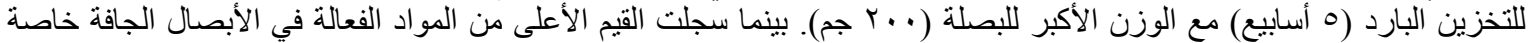

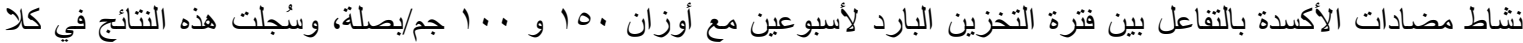

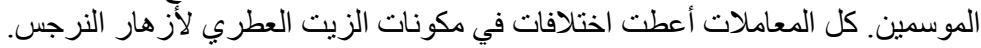

$$
\begin{aligned}
& \text { الكلمات الدالة: النرجس، التخزين المبرد، حجم البصلة، النمو والتزهير، المواد الفعالة، الفينولات، الفلافونيدات، نشاط مضادات الأكسدة، } \\
& \text { مكونات الزيت العطري. }
\end{aligned}
$$

